\title{
CHEMICAL PROPERTIES OF VOLCANIC SOIL AFFECTED BY SEVEN- YEAR ROTATIONS
}

\author{
Juan Hirzel $^{1 *}$, Pablo Undurraga ${ }^{1}$, and Jorge González ${ }^{1}$
}

\begin{abstract}
Long-term crop rotation systems can benefit soil chemical-physical properties and crop productivity. The lack of information on the effect of long-term crop rotations on soil chemical-physical properties for volcanic soils in Chile could restrict reaping real benefits, and make it difficult to take agricultural management decisions, which could lead to possible negative consequences on some soil chemical-physical properties and the environment. The development of information associated with the effect on soil chemical-physical properties with respect to long-term rotation systems and their fertilization management contribute to improving agronomic management decisions for these soils. A study was carried out to assess the effect of six rotation systems replicating fertilization management used by farmers, especially $\mathrm{N}$ and $\mathrm{P}$ application, and eventually low rates of $\mathrm{K}, \mathrm{Ca}$ and $\mathrm{Mg}$ on soil chemical properties in a volcanic soil after $7 \mathrm{yr}$ in Central South Chile. Affected chemical properties were $\mathrm{pH}$, inorganic $\mathrm{N}$, and available $\mathrm{K}$, along with a general decrease of $\mathrm{pH}$ related to fertilization used, which was insufficient in $\mathrm{Ca}, \mathrm{K}$, and $\mathrm{Mg}$. Moreover, this soil exhibited high P adsorption capacity (90.2 to 97.5\%). Hence, crop rotations that included pasture legumes and crops with high nutrient inputs such as sugar beet (Beta vulgaris L.) generated a less negative effect on soil chemical properties. This study indicates that fertilization management in crop rotation systems must consider the input and output nutrient balances to prevent the negative effect on some soil chemical properties.
\end{abstract}

Key words: crop rotation, Andisol, nutrient management, soil fertility.

$\mathrm{T}$ he use of inappropriate fertilization rates in crop production could generate problems by decreasing nutritional reserves associated with low input use or increasing some nutrients with negative effects on the environment when they are applied at rates higher than crop needs, thus generating soil and water contamination and soil acidification (Sims et al., 2000; Halvorson et al., 2004; Wivstad et al., 2005; Herencia et al., 2007; Undurraga et al., 2009). Monoculture or intensive rotations also decrease crop productivity and the negative effects on some soil properties with regard to the diversity of the rotation crops, especially when these are inadequately fertilized (Porter et al., 1997; Carpenter-Boggs et al., 2000; Sandoval et al., 2007; Stanger and Lauer, 2008).

Crop rotation allows an increasingly efficient use of nutrients applied as fertilizers, which decrease the risk of depletion of finite natural resources used for fertilizer

${ }^{1}$ Instituto de Investigaciones Agropecuarias INIA, Avenida Vicente Méndez 515, Chillán, Chile. *Corresponding author (jhirzel@inia.cl). Received: 27 August 2010.

Accepted: 15 February 2011. production; there is a need to provide fertilization rates appropriate for each crop. At the same time, sustainability of cropping systems requires that nutrients removed from the soil be balanced by the nutrients applied (Wivstad et al., 2005; Stanger and Lauer, 2008).

The principal nutrients applied for the non-legume crops were $\mathrm{N}$ and $\mathrm{P}$, whose rates were determined through different methods such as chemical indexes, aerobic incubations for N (Stanford and Smith, 1972; Hong et al., 1990; Laos et al., 2000), and chemical soil analysis for P. Although $\mathrm{P}$ requirements are generally low in crops (Lester et al., 2009), excessive rates could generate environmental problems in soils with low adsorption capacity (P accumulation capacity) as opposed to ash volcanic soils with high adsorption capacity and low pollution risk (Beck et al., 1998; Barreal et al., 2001; Haynes and Mokolobate, 2001). Other nutrients such as $\mathrm{K}, \mathrm{Ca}$, and $\mathrm{Mg}$ are partially applied according to soil content (especially $\mathrm{K})$, soil acidity $(\mathrm{Ca}$ and $\mathrm{Mg}$ ), or applied according to crop response. Moreover, they are considerable for crop and grasslanduptakes, which could negatively affect both fertility and productive soil 
capacity (Evers, 2002; McDonald, 2006; Hirzel et al., 2007; Shewmaker et al., 2008).

Volcanic soils in Chile represent 5288000 ha (Besoain, 1985), which cover 1\% of the earth's surface, but support $10 \%$ of the world's population, including some of the highest human population densities (Neall, 2006). Volcanic soils are found in Chile, Peru, Ecuador, Colombia, Central America, the United States, Kamchatka, Japan, the Philippines, Indonesia, New Zealand, and the independent Southwest Pacific Island states (Neall, 2006). Fertilization management in these soils under crop rotation systems mainly incorporates $\mathrm{N}$ and $\mathrm{P}$ in accordance with crop needs and their interaction with other soil properties, especially for P. Sugar beet (Beta vulgaris L.) and grassland crops include lime application. Applying $\mathrm{K}$ and $\mathrm{Mg}$ in volcanic and non-volcanic soils is not a common practice in all the important agricultural species or it is under crop needs, and respond to the low effect obtained with increased rates used in some crops as reported for $\mathrm{K}$ in corn (Hirzel et al., 2004; 2007) and ryegrass (Ruiz and Sadzawka, 2003). In addition, farmers who crop agricultural species such as those in this experiment usually use fertilization programs that allow decreasing the direct cost of each crop without considering future possible problems associated with using low rates of some nutrients. This generates two problems: negative effect on some of the principal soil chemical properties $(\mathrm{pH}, \mathrm{K}, \mathrm{Ca}$, or $\mathrm{Mg}$ ) and a possible decrease of the future yield of some crops.

Experimental results in Chile's ash volcanic soils indicate that crops that were adequately fertilized according to their soil chemical and physical characteristics yielded 27.0 to $37.0 \mathrm{Mg} \mathrm{ha}^{-1}$ for silage corn (Zea mays L.) (Soto et al., 2002; Hirzel et al., 2007), 8.3 to $10.6 \mathrm{Mg} \mathrm{ha}^{-1}$ for wheat (Triticum aestivum L.) (Mellado, 2000; Campillo et al., 2007; 2010), 3.8 to $4.7 \mathrm{Mg} \mathrm{ha}^{-1}$ for bean (Phaseolus vulgaris L.) (Tay et al., 2006), 14.1 to $18.2 \mathrm{Mg} \mathrm{DM} \mathrm{ha}^{-1}$ for lucerne (Medicago sativa L.) (Soto et al., 2000), and 13.5 to $15.7 \mathrm{Mg} \mathrm{DM} \mathrm{ha}^{-1}$ for red clover (Trifolium repens L.) (Ortega et al., 2003).

The objective was to determine the influence of six crop rotation systems and fertilization management to supply $\mathrm{N}$ and $\mathrm{P}$ needs after $7 \mathrm{yr}$ of crop rotations on chemical properties in a volcanic ash soil in Central South Chile.

\section{MATERIALS AND METHODS}

This study was conducted at the Santa Rosa Experimental Farm (36 $31^{\prime}$ S, 71 $\left.{ }^{\circ} 54^{\prime} \mathrm{W}\right)$, Instituto de Investigaciones Agropecuarias INIA, Chillán, Chile, between 1994 and 2002 in a silt loam volcanic soil (medial, amorphic, thermic Humic Haploxerands) (Stolpe, 2006). The soil's physical-
Table 1. Volcanic soil conditions in Central South Chile at soil depths of 0 to $20 \mathrm{~cm}$ at the start of the experiment.

\begin{tabular}{lc}
\hline Parameter & Value \\
\hline Bulk density, $\mathrm{Mg} \mathrm{m}^{-3}$ & 1.10 \\
Total porosity, \% & 58.5 \\
Water retention at 0.33 bars, \% & 30.0 \\
Water retention at 15 bars, \% & 15.2 \\
pH 1:2.5 soil:water & 6.4 \\
EC 1:5 soil: ${\text { water, } \mathrm{dS} \mathrm{m}^{-1}}_{\text {Organic C, } \mathrm{g} \mathrm{kg}^{-1}}^{0.03}$ \\
Inorganic N, $\mathrm{mg} \mathrm{kg}^{-1}$ & 61.1 \\
Olsen P, $\mathrm{mg} \mathrm{kg}$ & 13.0 \\
Available K, $\mathrm{cmol}_{\mathrm{c}} \mathrm{kg}^{-1}$ & 3.8 \\
\hline
\end{tabular}

EC: electrical conductivity.

chemical characteristics at the start of the crop rotation (0 to $20 \mathrm{~cm}$ depth) are shown in Table 1 . This soil had been previously cropped with oats (Avena sativa L.). The area has a Mediterranean climate with high temperatures and low rainfall and irrigation in the summer; and lower temperatures and high rainfall in the winter.

The experimental site was divided into a randomized complete block design with four replicates for each crop rotation treatment. Each experimental unit measured $7 \mathrm{x}$ $40 \mathrm{~m}$ and the total experimental area was $6720 \mathrm{~m}^{2}$.

All plots were cultivated with tillage and pesticides to optimize crop growth in accordance with standard agronomic practices indicated by several authors for Chile's central region in the six rotations being evaluated (Mellado, 2000; Soto et al., 2000; 2002; Ortega et al., 2003; Tay et al., 2006; Campillo et al., 2007; Hirzel et al., 2007). Crops and their fertilization are shown in Table 2. Harvest residues were removed each year. Fertilizers employed during the study period were urea $(\mathrm{N})$, triple superphosphate $\left(\mathrm{P}_{2} \mathrm{O}_{5}\right)$, potassium chloride $\left(\mathrm{K}_{2} \mathrm{O}\right)$, potassium magnesium sulfate $\left(\mathrm{MgO}, \mathrm{K}_{2} \mathrm{O}, \mathrm{S}\right)$, and calcium carbonate $(\mathrm{CaO})$.

Mechanically harvested grain (grain crops), roots (sugar beet, Beta vulgaris L.), and whole plants (silage corn, pastures, grain crops, and sugar beet) were sampled from each $1 \mathrm{~m}^{2}$ experimental unit in accordance with the crop rotation, suitable harvest stage, treatment, and year for yield and evaluation of whole plant nutrient uptake (nutrients harvest) . Dry matter content was determined by oven drying at $70{ }^{\circ} \mathrm{C}$ for $48 \mathrm{~h}$. Concentrations of plant $\mathrm{N}, \mathrm{P}, \mathrm{K}, \mathrm{Ca}$, and $\mathrm{Mg}$ were determined as follows: total $\mathrm{N}$ by macro-Kjeldahl procedure, total $\mathrm{K}, \mathrm{Ca}$, and $\mathrm{Mg}$ by ash drying at $500{ }^{\circ} \mathrm{C}$, acid digestion $(2 \mathrm{M} \mathrm{HCl})$, and atomic emission (K), as well as atomic absorption spectrophotometry ( $\mathrm{Ca}$ and $\mathrm{Mg}$ ). Phosphorus was measured in the same extracts by colorimetry following 
Table 2. Crop rotation and fertilization carried out from 1994 to 2000 in a volcanic soil in Central South Chile.

\begin{tabular}{|c|c|c|c|c|c|c|c|c|}
\hline \multirow{2}{*}{$\begin{array}{l}\text { Crop } \\
\text { rotation }\end{array}$} & \multirow[b]{2}{*}{ Fertilization } & \multicolumn{7}{|c|}{ Year } \\
\hline & & 1994 & 1995 & 1996 & 1997 & 1998 & 1999 & 2000 \\
\hline & & & & & $\mathrm{kg} \mathrm{ha}^{-1}$ & & & \\
\hline \multirow[t]{6}{*}{1} & & Red clover & Red clover & Sugar beet & Wheat & Red clover & Red clover & Sugar beet \\
\hline & $\mathrm{N}$ & 50 & 0 & 217 & 200 & 0 & 0 & 260 \\
\hline & $\mathrm{P}_{2} \mathrm{O}_{5}$ & 48 & 74 & 363 & 150 & 120 & 120 & 363 \\
\hline & $\mathrm{K}_{2} \mathrm{O}$ & 32 & 70 & 98 & 96 & 100 & 100 & 82 \\
\hline & $\mathrm{CaO}+$ & 0 & 0 & 1120 & 0 & 0 & 0 & 1120 \\
\hline & $\mathrm{MgO}$ & 0 & 0 & 0 & 0 & 0 & 0 & 43 \\
\hline \multirow[t]{6}{*}{2} & & Bean & Barley & Sugar beet & Wheat & Bean & Barley & Sugar beet \\
\hline & $\mathrm{N}$ & 100 & 90 & 217 & 200 & 100 & 120 & 260 \\
\hline & $\mathrm{P}_{2} \mathrm{O}_{5}$ & 92 & 165 & 363 & 150 & 100 & 130 & 363 \\
\hline & $\mathrm{K}_{2} \mathrm{O}$ & 96 & 98 & 98 & 96 & 100 & 60 & 82 \\
\hline & $\mathrm{CaO} \dagger$ & 0 & 0 & 1120 & 0 & 0 & 0 & 1120 \\
\hline & $\mathrm{MgO}$ & 0 & 0 & 0 & 0 & 0 & 0 & 43 \\
\hline \multirow[t]{6}{*}{3} & & Red clover & Red clover & Silage corn & Wheat & Red clover & Red clover & Silage corn \\
\hline & $\mathrm{N}$ & 50 & 6 & 300 & 200 & 0 & 0 & 300 \\
\hline & $\mathrm{P}_{2} \mathrm{O}_{5}$ & 48 & 74 & 97 & 150 & 120 & 120 & 120 \\
\hline & $\mathrm{K}_{2} \mathrm{O}$ & 32 & 58 & 35 & 96 & 100 & 100 & 120 \\
\hline & $\mathrm{CaO} \dagger$ & 0 & 0 & 0 & 0 & 0 & 0 & 0 \\
\hline & $\mathrm{MgO}$ & 0 & 0 & 0 & 0 & 0 & 0 & 0 \\
\hline \multirow[t]{6}{*}{4} & & Bean & Barley & Corn & Wheat & Bean & Barley & Corn \\
\hline & $\mathrm{N}$ & 100 & 90 & 300 & 200 & 100 & 120 & 300 \\
\hline & $\mathrm{P}_{2} \mathrm{O}_{5}$ & 92 & 165 & 97 & 150 & 100 & 130 & 120 \\
\hline & $\mathrm{K}_{2} \mathrm{O}$ & 96 & 98 & 35 & 96 & 100 & 60 & 120 \\
\hline & $\mathrm{CaO} \dagger$ & 0 & 0 & 0 & 0 & 0 & 0 & 0 \\
\hline & $\mathrm{MgO}$ & 0 & 0 & 0 & 0 & 0 & 0 & 0 \\
\hline \multirow[t]{6}{*}{5} & & Silage corn & & & Lucerne & & & Sugar beet \\
\hline & $\mathrm{N}$ & 350 & & & 0 & & & 260 \\
\hline & $\mathrm{P}_{2} \mathrm{O}_{5}$ & 120 & & & $101 \dagger \dagger$ & & & 363 \\
\hline & $\mathrm{K}_{2} \mathrm{O}$ & 104 & & & $74 \dagger \dagger$ & & & 82 \\
\hline & $\mathrm{CaO} \dagger$ & 0 & & & $314+\dagger$ & & & 1120 \\
\hline & $\mathrm{MgO}$ & 0 & & & 0 & & & 43 \\
\hline \multirow[t]{6}{*}{6} & & Silage corn & & White & clover $-r$ & egrass & & Sugar beet \\
\hline & $\mathrm{N}$ & 350 & & & 0 & & & 260 \\
\hline & $\mathrm{P}_{2} \mathrm{O}_{5}$ & 120 & & & $101 \dagger \dagger$ & & & 363 \\
\hline & $\mathrm{K}_{2} \mathrm{O}$ & 104 & & & $92 \dagger \dagger$ & & & 82 \\
\hline & $\mathrm{CaO} \dagger$ & 0 & & & 0 & & & 1120 \\
\hline & $\mathrm{MgO}$ & 0 & & & 0 & & & 43 \\
\hline
\end{tabular}

$\dagger$ Lime was the calcium source applied.

$\dagger \dagger$ Mean rate for the period.

the molybdate ascorbic acid method (Sadzawka et al., 2007). Results obtained for nutrient uptake in each treatment, except $\mathrm{N}$, during the 7 -yr rotation were compared with their respective input and an accumulated balance (input-output as fertilization and nutrient harvest) was then calculated, which allowed analyzing the effect of each rotation on some soil chemical properties. $\mathrm{N}$ balance was not determined because the rotations that included legume grass were not fertilized with this nutrient. 
Compound samples from 0 to $20 \mathrm{~cm}$ soil depths were collected manually from each treatment. Soil samples were air-dried and put through a $2-\mathrm{mm}$ sieve. Soil $\mathrm{pH}$ was determined in 1:2.5 soil:water extracts. Soil organic $\mathrm{C}$ was determined by Walkley-Black wet digestion. Soil inorganic $\mathrm{N}\left(\mathrm{NO}_{3}-\mathrm{N}\right.$ and $\left.\mathrm{NH}_{4}-\mathrm{N}\right)$ was extracted with $2 \mathrm{M}$ $\mathrm{KCl}$ and determined by colorimetry with a segmented flux spectrophotometer (Skalar autoanalyzer). Soil-extractable $\mathrm{P}$ was determined by the molybdate-ascorbic acid method and was $0.5 \mathrm{M} \mathrm{NaHCO}_{3}(\mathrm{Olsen} \mathrm{P})$. Soil available $\mathrm{K}$ was determined by $1 \mathrm{M} \mathrm{NH}_{4} \mathrm{OAc}$ extraction followed by flame emission spectrometry (Sadzawka et al., 2006). In addition, $\mathrm{P}$ adsorption was calculated as the difference between final and initial available $\mathrm{P}$ divided by $\mathrm{P}$ balance obtained during each 7-yr crop rotation:

$\mathrm{P}$ adsorption $(\%)=\left[\left(\mathrm{P}_{\mathrm{f}}-\mathrm{P}_{\mathrm{i}}\right) / \mathrm{P}\right.$ balance $] * 100$

where: $\mathrm{P}_{\mathrm{i}}=$ Olsen $\mathrm{P}$ at the start of the experiment $\left(\mathrm{mg} \mathrm{kg}^{-}\right.$ $\left.{ }^{1}\right) ; \mathrm{P}_{\mathrm{f}}=$ Olsen $\mathrm{P}$ at the end of year 7 of each crop rotation $\left(\mathrm{mg} \mathrm{kg}^{-1}\right) ; \mathrm{P}$ balance $=\mathrm{P}$ applied $-\mathrm{P}$ uptake $\left(\mathrm{mg} \mathrm{kg}^{-1}\right)$. The balance of $\mathrm{P}\left(\mathrm{mg} \mathrm{kg}^{-1}\right)$ was calculated to adjust $\mathrm{kg}$ ha ${ }^{-1}$ of $\mathrm{P}_{2} \mathrm{O}_{5}$ to bulk density (Table 1$)$, soil depth (0 to 20 $\mathrm{cm}$ ), and the relationship of $\mathrm{P}$ molecular weight over $\mathrm{P}_{2} \mathrm{O}_{5}$ (43.64\%). P uptake was calculated for the total dry matter and $\mathrm{P}$ concentration of each crop or pasture.

Data were analyzed with standard ANOVA procedures for a randomized complete block design. The main effect means were compared by the least significant difference (LSD) test. In addition, relationships between soil chemical parameters and accumulated nutrient balances were determined with a linear mathematical model. Significance was set at $\mathrm{p}<0.05$ (SAS Institute, 1990).

\section{RESULTS AND DISCUSSION}

\section{Agronomic behavior and nutritional balances of crop rotations}

Crop yields obtained in each rotation (Table 3) were generally lower than those indicated for the agricultural conditions of the study area with adequate fertilization management (Mellado, 2000; Soto et al., 2000; 2002; Ortega et al., 2003; Tay et al., 2006; Campillo et al., 2007; Hirzel et al., 2007; Campillo et al., 2010), and some crops included in different rotations exhibited differences in the same year. These lower yields were attributed to both low availability of some nutrients such as K (Table 1) and the deficient application for some crops (Table 2) according to nutritional needs (Benton, 1998; Havlin et al., 1999; Herencia et al., 2007; Hirzel et al., 2007), which is corroborated by the negative balance obtained for $\mathrm{K}$ and $\mathrm{Mg}$, and also for $\mathrm{Ca}$ in some crop rotations (Table 4). Furthermore, these results suggest that the soil critical nutritional references used for fertilization in Chilean volcanic soils with respect to potential crop production will be checked and corrected.

The accumulated nutrient balance (Table 4) is shown for each 7-yr crop rotation indicated insufficient $\mathrm{K}$ and $\mathrm{Mg}$ fertilization in all evaluated rotations. Two rotations without sugar beet and lucerne exhibited a negative $\mathrm{Ca}$ balance since $\mathrm{Ca}$ was regularly applied in these crops (Table 2). In general, all crops were fertilized with insufficient $\mathrm{K}, \mathrm{Mg}$, and $\mathrm{Ca}$ rates (Table 2) (Benton, 1998; Havlin et al., 1999; Herencia et al., 2007; Hirzel et al., 2007). All rotations obtained a positive P balance

Table 3. Yield range obtained for each crop rotation system from 1994 to 2000 ( $\left.\mathrm{Mg} \mathrm{ha}^{-1} \dagger\right)$ in a volcanic soil in Central South Chile.

\begin{tabular}{lccccccc}
\hline \multirow{2}{*}{$\begin{array}{l}\text { Crop } \\
\text { rotation }\end{array}$} & $\mathbf{1 9 9 4}$ & $\mathbf{1 9 9 5}$ & $\mathbf{1 9 9 6}$ & $\mathbf{1 9 9 7}$ & $\mathbf{1 9 9 8}$ & $\mathbf{1 9 9 9}$ & $\mathbf{2 0 0 0}$ \\
\hline 1 & Red clover & Red clover & Sugar beet & Wheat & Red clover & Red clover & Sugar beet \\
& $15.5-17.3$ & $12.0-13.9$ & $15.5-25.8$ & $6.9-7.7$ & $10.9-13.1$ & $7.3-9.3$ & $10.0-16.6$ \\
2 & Bean & Barley & Sugar beet & Wheat & Bean & Barley & Sugar beet \\
& $2.4-3.1$ & $3.7-4.1$ & $17.2-28.4$ & $5.5-6.8$ & $1.4-2.4$ & $4.5-6.2$ & $16.4-18.6$ \\
3 & Red clover & Red clover & Silage corn & Wheat & Red clover & Red clover & Silage corn \\
& $15.2-16.7$ & $11.9-13.4$ & $15.2-22.3$ & $5.5-6.1$ & $8.4-11.3$ & $7.9-8.4$ & $20.1-29.3$ \\
4 & Bean & Barley & Corn & Wheat & Bean & Barley & Corn \\
& $1.7-2.7$ & $3.7-6.1$ & $9.3-11.4$ & $5.4-6.6$ & $1.2-2.2$ & $4.8-6.1$ & $11.7-14.7$ \\
5 & Silage corn & & \multicolumn{7}{c}{ Lucerne } & & Sugar beet \\
& $18.6-23.6$ & $7.1-12.6$ & $18.5-21.7$ & $9.7-11.9$ & $6.7-9.4$ & $9.3-12.3$ & $12.8-18.1$ \\
6 & Silage corn & & \multicolumn{7}{c}{ White clover - ryegrass } & & Sugar beet \\
& $19.4-26.8$ & $8.1-12.0$ & $7.9-10.7$ & $5.4-9.1$ & $4.8-6.9$ & $6.9-8.5$ & $12.7-20.9$ \\
\hline
\end{tabular}

$\dagger$ Yield of the structure harvest expressed as dry matter (grain o whole plant according to each crop). 
Table 4. Accumulated nutrient input and output balance for the first 7 years of a crop rotation system $\dagger$ in a volcanic soil in Central South Chile.

\begin{tabular}{lccrc}
\hline $\begin{array}{l}\text { Crop } \\
\text { rotation } \dagger\end{array}$ & $\mathbf{P}$ & $\mathbf{K}$ & $\mathbf{C a}$ & $\mathbf{M g}$ \\
\cline { 2 - 5 } 1 & 261 & -1533 & 509 & -245 \\
2 & 403 & -875 & 1339 & -132 \\
2 & 69 & -1223 & -982 & -223 \\
3 & 182 & -728 & -257 & -136 \\
4 & 150 & -1439 & 593 & -233 \\
5 & 243 & -817 & 357 & -165 \\
6 & & &
\end{tabular}

$\nmid$ Nitrogen balance is not shown since two rotations included legume grass that did not receive this nutrient.

$\uparrow \dagger$ Crop rotations.

1 Red clover-red clover-sugar beet-wheat-red clover-red clover-sugar beet.

2 Bean-barley-sugar beet-wheat-bean-barley-sugar beet.

3 Red clover-red clover-silage corn-wheat-red clover-red clover-silage corn.

4 Bean-barley-corn-wheat-bean-barley-corn.

5 Silage corn-lucerne for 5 years-sugar beet.

6 Silage corn-white clover and ryegrass for 5 years-sugar beet.

because rates were higher than $\mathrm{P}$ requirements (Tables 2 and 4). Moreover, rotations 1 and 2 exhibited the highest accumulated $\mathrm{P}$ associated with $\mathrm{P}$ rates for the sugar beet crop (Tables 2 and 4).

\section{Effect of crop rotation on soil chemical properties}

Soil chemical analysis was carried out at a 0 to $20 \mathrm{~cm}$ depth at the end of rotation year 7 (Table 5) indicating that only $\mathrm{pH}$, inorganic $\mathrm{N}$, and $\mathrm{K}$ were affected by the evaluated crop rotations $(\mathrm{p}<0.05)$. Organic $\mathrm{C}$ and available $\mathrm{P}$ were not statistically affected by the different crop rotations
( $p>0.05$ ), but, in general, crop rotations exhibited a positive effect on these parameters. In addition, their contents increased with regard to the initial condition of the experiment. Organic C content and its evolution is also an indicator of soil quality (Doran and Parkin, 1994), and the increase obtained in all the evaluated rotations indicate that these rotations do not damage soil quality. Organic $\mathrm{C}$ value ranged from 65.0 to $71.5 \mathrm{~g} \mathrm{~kg}^{-1}$, and there were no differences among evaluated rotations. Some differences were found in the same experimental site at a 0 to $5 \mathrm{~cm}$ depth (Sandoval et al., 2007) while there were no differences at 5 to $20 \mathrm{~cm}$ (Undurraga et al., 2009). For other soil conditions, some authors also indicated that using different crop rotations in tillage conditions did not affect organic C content (Swift, 2001; Wivstad et al., 2005; Herencia et al., 2007).

In general, $\mathrm{pH}$ obtained in all rotations was lower than the initial value and ranged from 5.53 to 6.03 (Table 5); rotations fertilized with $\mathrm{Ca}$ exhibited a highly significant relationship with accumulated $\mathrm{Ca}$ (Figure 1), and a less significant relationship with negative $\mathrm{K}$ and $\mathrm{Mg}$ balances; moreover, the relation coefficient was low (0.38). The lowest $\mathrm{pH}$ value was obtained in rotation 3 associated with high nutrient uptake of alkaline reaction in the soil derived from crops such as red clover and silage corn, as well as the lack of $\mathrm{Ca}$ fertilization (lime application), and the use of urea as $\mathrm{N}$ fertilizer source (Rodriguez et al., 2008; Vieira et al., 2008). A higher acidification was expected for rotations 2 and 4, which used the higher $\mathrm{N}$ rates (urea) (Table 2); moreover, these rotations exhibited a less negative $\mathrm{Ca}$ balance than in rotation 3 (Table 4), which had the loweset $\mathrm{pH}$ (Table 5).

Inorganic $\mathrm{N}$ content ranged from 13.85 to 29.85 $\mathrm{mg} \mathrm{kg}^{-1}$ (Table 5, and differed between treatments $(\mathrm{p}<$

Table 5. Soil chemical properties at depths of 0 to $20 \mathrm{~cm}$ at the end of the $7^{\text {th }}$ rotation year for six crop rotation systems in a volcanic soil in Central South Chile.

\begin{tabular}{lccccc}
\hline Crop rotation $\dagger$ & $\mathbf{p H}$ & Organic $\mathbf{C}$ & Inorganic $\mathbf{N}$ & Olsen $\mathbf{P}$ & Available $\mathbf{K}$ \\
\hline & & $\mathrm{g} \mathrm{kg}^{-1}$ & - & & \\
1 & $5.98 \mathrm{a}$ & 71.5 & $25.50 \mathrm{a}$ & 7.75 & $\mathrm{mmol}_{\mathrm{c}} \mathrm{kg}^{-1}$ \\
2 & $6.03 \mathrm{a}$ & 65.0 & $13.85 \mathrm{c}$ & 8.25 & $0.095 \mathrm{~b}$ \\
3 & $5.53 \mathrm{~b}$ & 67.9 & $29.85 \mathrm{a}$ & 6.83 & $0.160 \mathrm{a}$ \\
4 & $5.88 \mathrm{a}$ & 65.5 & $22.68 \mathrm{ab}$ & 8.43 & $0.086 \mathrm{~b}$ \\
5 & $5.87 \mathrm{a}$ & 70.9 & $24.60 \mathrm{ab}$ & 6.25 & $0.079 \mathrm{~b}$ \\
6 & $5.88 \mathrm{a}$ & 68.6 & $17.35 \mathrm{bc}$ & 8.00 & $0.083 \mathrm{~b}$ \\
\hline
\end{tabular}

Different letters in the same column indicate statistical differences between treatments $(p<0.05)$.

$\dagger$ Crop rotations.

1 Red clover-red clover-sugar beet-wheat-red clover-red clover-sugar beet.

2 Bean-barley-sugar beet-wheat-bean-barley-sugar beet.

3 Red clover-red clover-silage corn-wheat-red clover-red clover-silage corn.

4 Bean-barley-corn-wheat-bean-barley-corn.

5 Silage corn-lucerne for 5 years-sugar beet.

6 Silage corn-white clover and ryegrass for 5 years-sugar beet. 


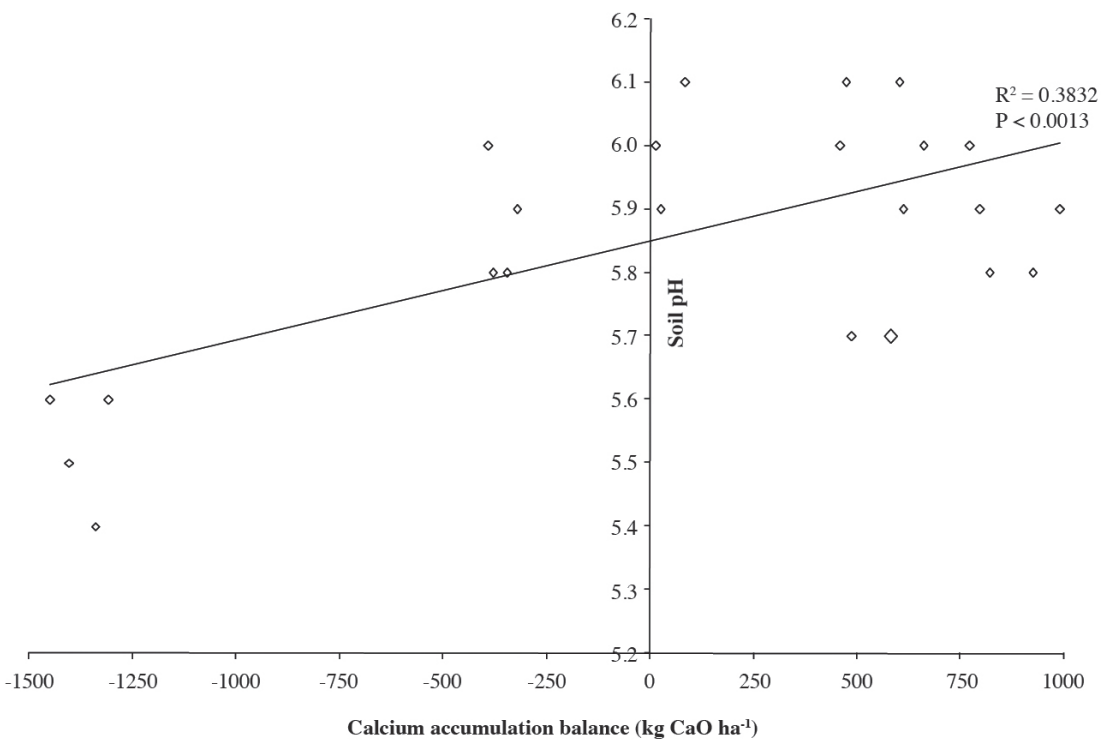

Figure 1. Relationship between soil $\mathrm{pH}$ and calcium accumulation balance at the end of the $7^{\text {th }}$ year of the experiment.

$0.05)$. The highest values were obtained in rotations 1 and 3 (which included red clover) and only differed from rotations 2 (bean-barley-sugar beet-wheat-bean-barleysugar beet) and 6 (silage corn-white clover and ryegrass for $5 \mathrm{yr}$-sugar beet). These differences can be attributed to the fact that rotation 2 did not include pasture and rotation 6 included a low $\mathrm{N}$ input pasture (Table 2). Carpenter-Boggs et al. (2000) indicate differences with another $\mathrm{N}$ availability index (net mineralized $\mathrm{N}$ ) in connection with different crop rotations including corn (Zea mays L.), soybean (Glycine max (L.) Merr.), wheat (Triticum aestivum L.), and lucerne (Medicago sativa L.) in non-volcanic soils where higher $\mathrm{N}$ values were obtained in rotations with lucerne. Rotation 5, which included only lucerne, showed an increase in available $\mathrm{N}$ with respect to rotations 2 and 6; moreover, its yield was lower than values indicated by Soto et al. (2000) for the same study area, which is associated with both its atmospheric $\mathrm{N}$ fixation capacity and residual $\mathrm{N}$ in the soil. Neall (2006) indicated that in some volcanic soil, especially younger volcanic materials, time can limit $\mathrm{N}$ buildup in the soil, associated with some pastures that fix $\mathrm{N}$ in a serial succession to more $\mathrm{N}$-demanding plants.

Available $\mathrm{P}$ showed no differences among the six evaluated rotations $(p>0.05)$ and fluctuated between 6.25 and $8.43 \mathrm{mg} \mathrm{kg}^{-1}$ (Table 5). These values were lower than those indicated by Essington and Howard (2000) for the first $15 \mathrm{~cm}$ soil depth at the end of a long-term rotation with wheat and corn fertilized with rates of $137.4 \mathrm{~kg} \mathrm{P}_{2} \mathrm{O}_{5}$ $\mathrm{ha}^{-1}$ on non-volcanic soil. Furthermore, the relationship between available $\mathrm{P}$ and accumulated $\mathrm{P}$ balance was analyzed, but the correlation index and significance level were very low. Figure 2 shows the $\mathrm{P}$ adsorption coefficient at the end of year 7 of the experiment. Although there were differences in the $\mathrm{P}$ adsorption coefficient, the lowest value was obtained in rotation 3 (Figure 2) probably because of both high accumulated $\mathrm{P}$ uptake and lower $\mathrm{P}$ balance (Table 4). The $\mathrm{P}$ adsorption coefficient was high in all treatments and its value fluctuated between 90.2 and $97.5 \%$, thus responding to the high P fixation capacity of this soil (Beck et al., 1998; Barreal et al., 2001; Haynes and Mokolobate, 2001).

Available K values ranged from 0.079 to 0.208 $\mathrm{cmol}_{(+)} \mathrm{kg}^{-1}$ (Table 5) with differences among rotations ( $\mathrm{p}$ $<0.05)$. The highest values were obtained in rotations 2 and 4 probably given the less negative balance calculated for these treatments (Table 4) and their lower K uptake. For treatments 2 and 4, the available $\mathrm{K}$ value increased with respect to the initial experimental condition, which can respond to this soil's low K fixation (Morton et al., 2004) and K supply capacity probably due to the cationic competition mechanism in the adsorption sites (Escudey $e t$ al., 1997) and the higher $\mathrm{pH}$ obtained for those treatments (Table 5) (Cáceres-Jensen et al., 2009).

In general, evaluated crop rotations do not differentially affect soil quality parameters tested in this experiment; moreover, chemical soil properties were affected. The most favorable crop rotations for this experiment were those that included crops with nutrient use higher or approximate to crop needs, and pasture legumes. 


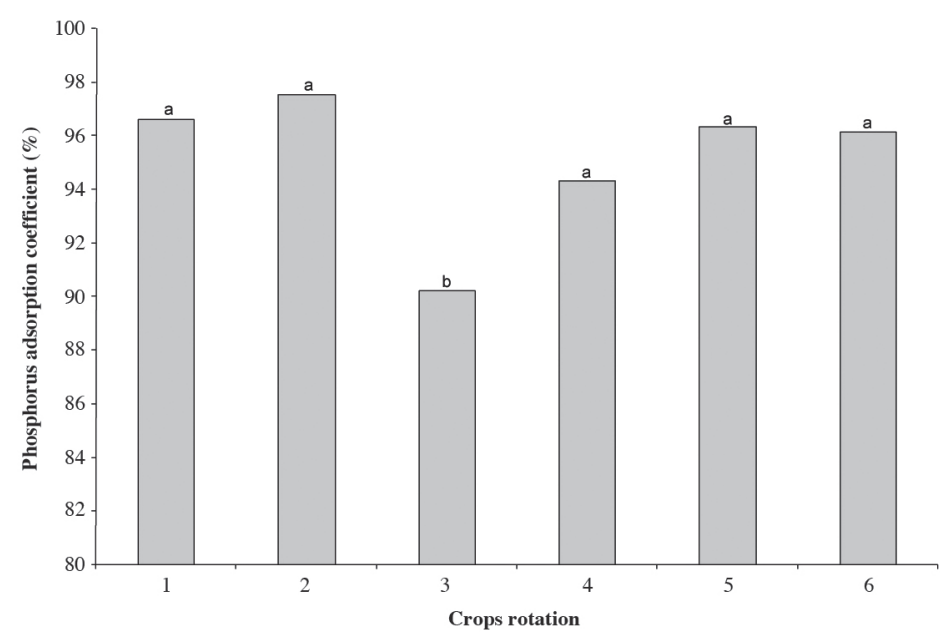

Different letters over the bars indicate statistical differences between treatments $(\mathrm{p}<0.05)$.

1 Red clover-red clover-sugar beet-wheat-red clover-red clover-sugar beet.

2 Bean-barley-sugar beet-wheat-bean-barley-sugar beet.

3 Red clover-red clover-silage corn-wheat-red clover-red clover-silage corn.

4 Bean-barley-corn-wheat-bean-barley-corn.

5 Silage corn-lucerne for 5 years-sugar beet.

6 Silage corn-white clover and ryegrass for 5 years-sugar beet.

Figure 2. Phosphorus adsorption coefficient obtained after 7 years of each crop rotation.

\section{CONCLUSION}

Among the soil chemical properties evaluated in volcanic soil cultivated with different crop rotation systems, fertilization management used by farmers mainly focused on $\mathrm{N}$ and $\mathrm{P}$ applications, which negatively affected $\mathrm{pH}$ and frequently available $\mathrm{K}$, and do not allow to achieve the yield potential reported for this agricultural area. Results also indicated the positive effect of including pasture legumes and crops with high nutrient inputs, such as sugar beet, in a long-term crop rotation, which contribute to conserving soil chemical properties. To generate soil resource sustainability and improve crop productivity, in addition to using high rates of $\mathrm{N}$ and $\mathrm{P}$, crops must be fertilized with nutrients such as $\mathrm{Ca}, \mathrm{Mg}$, and $\mathrm{K}$ in connection with their nutritional requirements and input and output nutrient balances must be considered in the long-term. Results also allowed assessing the volcanic soil $\mathrm{P}$ adsorption coefficient in a long-term experiment under field conditions. Finally, the organic $\mathrm{C}$ value obtained suggests that the evaluated crop rotations do not affect soil quality.

\section{RESUMEN}

Propiedades químicas del suelo volcánico afectado por rotaciones de siete años. Los sistemas de rotación de cultivos de largo plazo pueden tener varios beneficios sobre las propiedades físico-químicas del suelo y productividad de los cultivos. La falta de información sobre el efecto de rotaciones de largo plazo en las propiedades físico- químicas para suelos volcánicos en Chile podría limitar la obtención de beneficios reales, dificultando decisiones de manejo agrícola, con posibles consecuencias negativas en las propiedades físico-químicas del suelo y el ambiente. El desarrollo de información asociada a efectos en las propiedades físico-químicas del suelo en relación al uso de diferentes sistemas de rotaciones de largo plazo y sus manejos de fertilización, podrían contribuir a mejorar las decisiones de manejo agronómico en estos suelos. Se realizó un estudio que evaluó el efecto de seis rotaciones de cultivo que representan el manejo de fertilización utilizado por agricultores, que enfatiza la aplicación de $\mathrm{N}$ y $\mathrm{P}$ y eventualmente baja dosis de $\mathrm{K}$, Ca y $\mathrm{Mg}$, sobre las propiedades químicas de un suelo volcánico del centrosur de Chile después de 7 años. Las propiedades químicas afectadas fueron $\mathrm{pH}, \mathrm{N}$ inorgánico y $\mathrm{K}$ disponible, con una disminución general del $\mathrm{pH}$ relacionada con la fertilización usada, insuficiente en $\mathrm{Ca}, \mathrm{K}$ y $\mathrm{Mg}$. A su vez este suelo presentó una alta capacidad de adsorción de $\mathrm{P}$ (90,2-97,5\%). Consecuentemente, las rotaciones de cultivo que incluyeron leguminosas forrajeras y cultivos con altos ingresos de nutrientes como remolacha generaron un efecto menos negativo en las propiedades químicas del suelo. Para prevenir efectos negativos sobre las propiedades químicas del suelo como lo indicado en este estudio, el manejo de fertilización en sistemas de rotaciones de cultivos debería considerar balances de entrada y salida de nutrientes.

Palabras clave: rotación de cultivos, Andisol, manejo de nutrientes, fertilidad de suelos. 


\section{LITERATURE CITED}

Barreal, M.E., M. Camps Arbestain, F. Macías, and A.E. Fertita. 2001. Phosphate and sulfate retention by nonvolcanic soils with andic properties. Soil Science 166:691-707.

Beck, M., W. Robarge, and S. Buol. 1998. Phosphorus retention and release of anion and organic carbon by two Andisols. European Journal of Soil Science 50:157-164.

Benton, J. 1998. Plant nutrition manual. CRC Press, Florida, USA.

Besoain, E. 1985. Los suelos. P 25-95. In: Suelos volcánicos de Chile, J. Tosso (Ed.) INIA, Santiago, Chile, 723 p.

Cáceres-Jensen, L., J. Gan, M. Baez, R. Fuentes, and M. Escudey. 2009. Adsorption of glyphosate on variable-charge, volcanic ash-derived soils. Journal of Environment Quality 38:1449-1457.

Campillo, R., C. Jobet, and P. Undurraga. 2007. Optimization of the nitrogen fertilization to wheat of high yield potential in Andisols of Araucania Region, Chile. Agricultura Técnica (Chile) 67:281-291.

Campillo, R., C. Jobet, and P. Undurraga. 2010. Effects of nitrogen on productivity, grain quality, and optimal nitrogen rates in winter wheat cv. Kunpa-INIA in Andisols of Southern Chile. Chilean Journal of Agricultural Research 70:122-131.

Carpenter-Boggs, L., J.L. Pikul Jr., M.F. Vigil, and W.E. Riedell. 2000. Soil nitrogen mineralization influenced by rotation and nitrogen fertilization. Soil Science Society of America Journal 64:2038-2045.

Doran, J., and T. Parkin. 1994. Defining and assessing soil quality. 244 p. In Doran, J., D.C. Coleman, D.F. Bezdicek, and B.A. Stewart (eds.) Defining soil quality for a sustainable environment. Soil Science Society of America, Madison, Wisconsin, USA.

Escudey, M., P. Díaz, J.E. Foerster, and G. Galindo. 1997. Adsorbed ion activity coefficients in K-Ca exchange on soil fractions derived from volcanic materials. Australian Journal of Soil Research 35:123-130.

Essington, M.E., and D.D. Howard. 2000. Phosphorus availability and speciation in long-term no-till and disk-till soil. Soil Science 165:144-152.

Evers, G.W. 2002. Ryegrass-bermudagrass production and nutrient uptake when combining nitrogen fertiliser with broiler litter. Agronomy Journal 94:905-910.

Halvorson, A.D., D.C. Nielsen, and C.A. Reule. 2004. Nitrogen fertilization and rotation effects on notill dryland wheat production. Agronomy Journal 96:1196-1201.
Havlin, J.L., J.D. Beaton, S.L. Tisdale, and W.H. Nelson. 1999. Soil fertility and fertilizers. An introduction to nutrient management. $6^{\text {th }}$ ed. Prentice-Hall, New Jersey, USA.

Haynes, R.J., and M.S. Mokolobate. 2001. Amelioration of $\mathrm{Al}$ toxicity and $\mathrm{P}$ deficiency in acid soils by additions of organic residues: a critical review of the phenomenon and the mechanisms involved. Nutrient Cycling in Agroecosystems 59:47-63.

Herencia, J.F., J.C. Ruiz-Porras, S. Melero, P.A. Garcia-Galavis, E. Morillo, and C. Maqueda. 2007. Comparison between organic and mineral fertilization on soil fertility levels, crop macronutrient concentrations, and yield. Agronomy Journal 99:973-983.

Hirzel, J., I. Matus, F. Novoa, and I. Walter. 2007. Effect of poultry litter on silage maize (Zea mays L.) production and nutrient uptake. Spanish Journal of Agricultural Research 5:102-109.

Hirzel, J., N. Rodríguez, and E. Zagal. 2004. Effect of different doses of $\mathrm{N}, \mathrm{P}, \mathrm{K}$ inorganic fertilization and organic source (poultry litter) on maize production and soil fertility. Agricultura Técnica (Chile) 64:365-374.

Hong, S.D., R.H. Fox, and W.P. Piekielek. 1990. Field evaluation of several chemical indexes of soil nitrogen availability. Plant and Soil 123:83-88.

Laos, F., P. Satti, I. Walter, M.J. Mazzarino, and S. Moyano. 2000. Nutrient availability of composted and noncomposted residues in a Patagonian Xeric Mollisol. Biology and Fertility of Soils 31:462-469.

Lester, D.W., C.J. Birch, and C.W. Dowling. 2009. Fertiliser $\mathrm{N}$ and $\mathrm{P}$ applications on two Vertisols in north-eastern Australia. 2. Grain P concentration and removal in grain from long-term experiments. Crop \& Pasture Science 60:218-229.

McDonald, G.K. 2006. Effects of soil properties on variation in growth, grain yield and nutrient concentration of wheat and barley. Australian Journal of Experimental Agriculture 46:93-105.

Mellado, M. 2000. Genetic improvement in bread wheats (Triticum aestivum L.) in the South Central area of Chile: Analysis of grain yield and related variables in spring varieties. Agricultura Técnica (Chile) 60:32-42.

Morton, J.D., C.G. Roach, M.J. Tong, and A.H.C. Roberts. 2004. Potassium in soil and pasture and leaching of cations on an allophanic soil in New Zealand. New Zealand Journal of Agricultural Research 47:147-154.

Neall, V.E. 2006. Volcanic soils. Encyclopedia of Life Support Systems (EOLSS). Land use and land cover VII:1-24. Available at http://www.eolss.net/ebooks/ Sample\%20Chapters/C19/E1-05-07-13.pdf (accessed April 2010). 
Ortega, F., R. Galdames, A. Aguilera, O. Romero, I. Ruiz, P. Soto, and A. Torres. 2003. Redqueli-INIA, new red clover synthetic cultivar. Agricultura Técnica (Chile) 63:207-211.

Porter, P.M., J.G. Lauer, W.E. Lueschen, J.H. Ford, T.R. Hoverstad, E.S. Oplinger, and R.K. Crookston. 1997. Environment affects the corn and soybean rotation effect. Agronomy Journal 89:441-448.

Rodriguez, M.B., A. Godeas, and R.R. Lavado. 2008. Soil acidity changes in bulk soil and maize rhizosphere in response to nitrogen fertilization. Communications in Soil Science and Plant Analysis 39:2597-2607.

Ruiz, R., and A. Sadzawka. 2003. Use of chemical analysis of soil potassium as an indicator of potassium in venes and modification by potassium fertilization. Agricultura Técnica (Chile) 63:48-58.

Sadzawka, A, M.A. Carrasco, R. Demanet, H. Flores, R. Grez, M.L. Mora, y A. Neaman. 2007. Métodos de análisis de tejidos vegetales. Segunda Edición. Serie Actas $\mathrm{N}^{\circ}$ 40. Instituto de Investigaciones Agropecuarias INIA, Santiago, Chile.

Sadzawka, A., M.A. Carrasco, R. Grez, M.L. Mora, H. Flores, y A. Neaman. 2006. Métodos de análisis de suelos recomendados para los suelos de Chile. Revisión 2006. Serie Actas $N^{\circ}$ 34. Instituto de Investigaciones Agropecuarias INIA, Santiago, Chile.

Sandoval, M.A., N.B. Stolpe, E.M. Zagal, and M. Mardones. 2007. The effect of crop-rotations on the $\mathrm{C}, \mathrm{N}$ and $\mathrm{S}$ contents of soil aggregates and structural stability in a volcanic soil of south-central Chile. Acta Agriculturæ Scandinavica 57:255-262.

SAS Institute. 1990. Usage and reference. Version 6. SAS Institute Inc., Cary, North Carolina, USA.

Shewmaker, G.E., D.A. Johnson, and H.F. Mayland. 2008. $\mathrm{Mg}$ and $\mathrm{K}$ effects on cation uptake and dry matter accumulation in tall fescue (Festuca arundinacea). Plant and Soil 302:283-295.

Sims, J.T., A.C. Edwards, O.F. Schoumans, and R.R. Simard. 2000. Integrating soil phosphorus testing into environmentally based agricultural management practices. Journal of Environmental Quality 29:60-71.
Soto, P., E. Jahn, and S. Arredondo. 2002. Planting density and nitrogen fertilization of hybrid corn for silage in the irrigated central valley. Agricultura Técnica (Chile) 62:255-265.

Soto, P., E. Jahn, I. Maldonado, and N. Rodríguez. 2000. Alfalfa (Medicago sativa L.) improvement with fertilization in different soil conditions. Agricultura Técnica (Chile) 60:236-250.

Stanford, G., and S.J. Smith. 1972.Nitrogen mineralization potentials of soils. Soil Science Society of America Journal 36:465-472.

Stanger, T.F., and J.G. Lauer. 2008. Corn grain yield response to crop rotation and nitrogen over 35 years. Agronomy Journal 100:643-650.

Stolpe, N.B. 2006. Descripción de los principales suelos de la VIII Región de Chile. Departamento de Suelos y Recursos Naturales, Facultad de Agronomía, Universidad de Concepción, Chillán, Chile.

Swift, R.S. 2001. Sequestration of carbon by soil. Soil Science 166:858-871.

Tay, J., A. France, and A. Pedreros. 2006. Astro-INIA: first green shelled Coscorron type bean variety with a determinate bush growth habit. Agricultura Técnica (Chile) 66:416-419.

Undurraga, P., E. Zagal, G. Sepúlveda, and N. Valderrama. 2009. Dissolved organic carbon and nitrogen in Andisol for six crop rotations with different soil management intensity. Chilean Journal of Agricultural Research 69:445-454

Vieira, F.C.B., C. Bayer, J. Mielniczuk, J. Zanatta, and C.A. Bissani. 2008. Long-term acidification of a Brazilian Acrisol as affected by no till cropping systems and nitrogen fertilizer. Australian Journal of Soil Research 46:17-26.

Wivstad, M.,A.S. Dahlin, and C. Grant. 2005. Perspectives on nutrient management in arable farming systems. Soil Use Management 21:113-121. 